\title{
Analysis on the value of alternative restoration of ecological environmental damage in a company's greening scheme
}

\author{
Lin Wang ${ }^{1 *}$, Jing Liu ${ }^{2}$, Desheng Wang ${ }^{3}$, Shiyu Wang ${ }^{2}$, Yan Jiang ${ }^{1}$, Milan Wang ${ }^{1}$, Zhiguo Liu ${ }^{4}$ \\ ${ }^{1}$ Institute of Environmental and Chemical Engineering, Dalian University, Dalian, 116622, China \\ ${ }^{2}$ Liaoning Branch of Beijing Zhonghuan Bohong Environmental Resources Technology Co., Ltd, Shenyang, 110623, China; \\ ${ }^{3}$ Liaoning Science and Technology Center for ecological environment protection, Shenyang, 116011, China \\ ${ }^{4}$ College of Information Engineering, Dalian University, Dalian, 116622, China
}

\begin{abstract}
In this paper, a company greening plan to evaluate ecological service function and value analysis, to determine whether a company greening scheme to the excess emissions of alternative to repair the enterprise ecological environmental damage caused by the results show that a company in September 2019 2020 at the end of greening measures total carbon release oxygen value of 605000 yuan, including carbon value of 278900 yuan, releasing oxygen value of 326100 yuan. The total value of the greening measures taken by the enterprise from September 2019 to the end of 2020 is 16,300 yuan, of which the value of providing negative ions is 12, 300 yuan, and the value of absorbing pollutants and catching dust is 4, 000 yuan. The ecological service function of the greening scheme can partially offset the ecological environmental damage caused by the excessive emission of enterprises.
\end{abstract}

\section{Introduction}

Damage to the ecological environment refers to adverse changes in environmental elements such as the atmosphere, surface water, groundwater, soil and forests and biological elements such as plants, animals and microorganisms, as well as degradation of the functions of the ecosystem constituted by the above-mentioned elements as a result of environmental pollution or ecological destruction. Negotiable, damage to the environment, liability of ecological environment damage compensation system for ecological environmental damage caused by the units or individuals for larger compensation for environmental pollution and ecological destruction events, including clean up pollution cost, and ecological environment restoration cost, the service function of ecological environment during the repair damage, the ecological environment function reasonable expenses such as the loss caused by permanent damage. If the damage to the ecological environment cannot be repaired, monetary compensation shall be made to replace the repair.

In the practice of ecological and environmental damage compensation system reform, people continue to explore diversified liability modes. A company plans to create new ecological service functions through reasonable greening scheme, so as to realize the alternative repair of the ecological damage caused by the enterprise's excessive emissions.

\section{Research background}

In 2019, the central ecological and environmental protection supervision found that a company had problems such as abnormal operation of online monitoring facilities and excessive emissions, etc. From 2014 to 2018, a company was subjected to 40 administrative penalties by the Yingkou Municipal Bureau of Ecology and Environment for excessive emissions from exhaust gas outlets such as the secondary dust removal port of converter and No. 1 gas emission tower.

In August 2020, according to the compensation reform system for ecological and environmental damage, Yingkou Municipal Bureau of Ecology and Environment started the compensation work for ecological and environmental damage caused by air pollution of a certain company. According to the compensation system for ecological and environmental damage, if the ecological and environmental damage caused cannot be repaired, compensation for damages can be carried out in combination with the ecological and environmental damage in the region.

Plant greening can improve the ecological environment effect, affect the nearby wind, temperature, humidity, etc., can purify the air, absorb the harmful gases discharged in the process of industrial production, and play a role in filtering and blocking the smoke and dust in the air. A company intends to improve the greening rate on a large scale inside the factory, and effectively improve the local ecological environment through large-scale planting of various shrubs and tree species such as Euonymus

* Corresponding author: 309098628@qq.com 
officinale and Martyllanthus, and the resulting environmental benefits can partially offset the damage to the ecological environment caused by the excessive emissions of the enterprise from January 15, 2014 to July 4, 2016.

Combined with the actual construction situation of the factory of a certain company and the ecological service functions listed in the Forest Ecosystem Service Function Assessment Specification (GB/T 38582-2020), the important service functions of the plant greening work of this project are carbon fixation and oxygen release and atmospheric environment purification. This paper analyzed the ecological service value of the greening scheme in the factory area of a company limited liability company from two aspects of carbon fixation, oxygen release and air purification.

\section{Evaluation of carbon fixation and oxygen release value}

Carbon sequestration, also known as carbon sequestration, can be achieved through physical carbon sequestration and biological carbon sequestration, so that carbon dioxide can be stored in oil and gas Wells, coal seams and deep sea, or the ability of carbon absorption and storage of organisms can be improved to reduce carbon dioxide emissions in the atmosphere. Oxygen release refers to the fact that substances can undergo very complex chemical changes to release oxygen. Plants can absorb carbon dioxide from the air, convert it into oxygen through photosynthesis, and release it into the air.

\subsection{Carbon sequestration value}

\subsubsection{Calculation method}

According to the Code for Assessment of Forest Ecosystem Services (GB/T 38582-2020), the calculation formula of ecosystem carbon sequestration value is as follows:

$$
\begin{aligned}
& \mathrm{U}_{\mathrm{c}}=\mathrm{G}_{\mathrm{c}} \times \mathrm{C}_{\mathrm{c}} ; \\
& \mathrm{G}_{\mathrm{c}}=\mathrm{G}_{\text {Vegetation carbon sequestration }}+\mathrm{G}_{\text {Soil carbon sequestration; }} \\
& \mathrm{G}_{\text {Vegetation carbon sequestration }}=1.63 \mathrm{R}_{\mathrm{C}} \times \mathrm{A} \times \mathrm{B}_{\text {Year }} \times \mathrm{F} ; \\
& \mathrm{G}_{\text {Soil carbon sequestration }}=\mathrm{A} \times \mathrm{S}_{\text {soil }} \times \mathrm{FG} ;
\end{aligned}
$$

$\mathrm{G}_{\mathrm{C}}$ is the annual carbon sequestration amount of stand ecosystem, unit: $t \cdot \mathrm{a}^{-1} ; \mathrm{G}$ vegetation carbon sequestration is the annual carbon sequestration amount of the stand, unit $: \mathrm{t}^{\cdot} \mathrm{a}^{-}$ 1; $\mathrm{G}$ soil carbon sequestration is the annual soil carbon sequestration amount corresponding to stand year, unit $: \mathrm{t} \cdot \mathrm{a}^{-1} ; \mathrm{R}_{\mathrm{C}}$ is the content of carbon in carbon dioxide, which is $27.27 \%$; A stands area, unit $: \mathrm{h} \mathrm{m}^{2}$; $\mathrm{B}_{\text {Year }}$ is the measured stand productivity, unit $: t \cdot \mathrm{hm}^{-2} \cdot \mathrm{a}^{-1} ; \mathrm{F}$ is the correction coefficient of forest ecosystem services (the same below); $\mathrm{S}_{\text {soil }}$ is the measured carbon fixation amount of stand soil per unit area, unit $: \mathrm{t} \cdot \mathrm{hm}^{-2} \cdot \mathrm{a}^{-1} ; \mathrm{C}_{\text {carbon }}$ is carbon fixation price, unit: yuan $\cdot \mathrm{a}^{-1}$.

\subsubsection{Determination of parameters}

(1) Net productivity of stand (BYear)
The area where the project is located belongs to the temperate zone, and the zonal vegetation type is coldtolerant subtropical plant. The annual net increase biomass of forest type in Liaoning Province was adopted for this assessment, and the net productivity of stand is shown in Table 1.

Table1. Net stand productivity

\begin{tabular}{|c|c|c|c|}
\hline project & units & $\begin{array}{c}\text { broad- } \\
\text { leaved } \\
\text { forest }\end{array}$ & $\begin{array}{c}\text { coniferou } \\
\text { s fores }\end{array}$ \\
\hline $\begin{array}{c}\text { net stand } \\
\text { productivity }\end{array}$ & $\mathrm{t} \cdot \mathrm{hm}^{-2} \cdot \mathrm{a}^{-1}$ & 13.75 & 15.883 \\
\hline
\end{tabular}

(2) Carbon sequestration price $\left(\mathrm{C}_{\mathrm{C}}\right)$

The carbon sequestration price adopts the Swedish carbon tax rate of USD 150 per ton (equivalent to RMB 1200 per ton), so it is calculated as RMB $1200 / \mathrm{t}$.

(3) Annual soil carbon sequestration per unit area of stand $\left(\mathrm{S}_{\mathrm{soil}}\right)$

The annual carbon sequestration amount of forest types in Liaoning Province was adopted in this assessment and the annual carbon sequestration amount of soil per unit area of stand is shown in Table 2.

Table 2. Annual carbon sequestration per unit area of stand

\begin{tabular}{|c|c|c|c|}
\hline project & units & $\begin{array}{c}\text { broad-leaved } \\
\text { forest }\end{array}$ & $\begin{array}{c}\text { conifero } \\
\text { us fores }\end{array}$ \\
\hline $\begin{array}{c}\text { Annual carbon } \\
\text { sequestration per } \\
\text { unit area of stand }\end{array}$ & $\begin{array}{c}\mathrm{t} \cdot \mathrm{hm}^{-} \\
2\end{array}$ & 6.19 & 7.15 \\
\hline
\end{tabular}

\section{(4) Stand area (A)}

This time according to the unit area of $1 \mathrm{H}$ square meters for calculation.

(5) Forest ecosystem service correction factor (F)

According to Table 1 of Code for Assessment of Forest Ecosystem Services (GB/T 38582-2020), the formula for calculating the correction coefficient of forest ecosystem services is as follows:

$$
F E S-C C=\frac{B_{e}}{B_{0}}=\frac{B E F * V}{B_{0}}
$$

FES-CC is the correction coefficient of forest ecosystem services; $\mathrm{Be}$ is the biomass of the stand, unit: $\mathrm{kg} \cdot \mathrm{m}-3$; Bo is the measured biomass of the stand $(\mathrm{kg} \cdot \mathrm{m}$ $3)$; BEF was the conversion factor between stock volume and biomass. $\mathrm{V}$ is the stock volume of the stand, unit: $\mathrm{m}^{3}$.

According to calculation, the correction coefficient of forest ecosystem services within the scope of this assessment is 1 .

\subsubsection{Calculation Results}

According to the carbon sequestration price per unit area, the annual carbon sequestration value of the greening measures and the annual carbon sequestration value of the soil adopted by a company limited liability company from 2019 to 2020 are calculated as shown in Table 3. 
Table 3. Annual carbon sequestration value of greening measures and annual carbon sequestration value of soil from September 2019 to the end of 2020

\begin{tabular}{|c|c|c|c|c|c|c|}
\hline Year & Type & $\begin{array}{c}\text { Vegetation } \\
\text { type }\end{array}$ & $\begin{array}{c}\text { Annual carbon } \\
\text { sequestration } \\
\text { value of stand } \\
\text { per unit } \\
\text { area } \cdot \mathbf{h m}^{-2} \cdot \mathbf{a}^{-1}\end{array}$ & $\begin{array}{c}\text { Forest area } / h \\
\mathrm{~m}^{2}\end{array}$ & $\begin{array}{c}\text { Annual carbon } \\
\text { sequestration } \\
\text { value of } \\
\text { stand } / \text { ten } \\
\text { thousand } \\
\text { yuan } \cdot \mathbf{a}^{-1} \\
\end{array}$ & $\begin{array}{c}\text { Total annual } \\
\text { carbon } \\
\text { sequestration } \\
\text { value of stand } \\
\text { / ten thousand } \\
\text { yuan } \cdot \mathbf{a}^{-1} \\
\end{array}$ \\
\hline \multirow{2}{*}{$\begin{array}{c}2019(9 \\
\sim 12 \\
\text { months) }\end{array}$} & \multirow[t]{2}{*}{$\begin{array}{l}\text { Trees, } \\
\text { shrubs }\end{array}$} & $\begin{array}{l}\text { broad-leaved } \\
\text { forest }\end{array}$ & 14762.27 & 1.29 & 1.90 & \multirow[t]{2}{*}{8.06} \\
\hline & & $\begin{array}{l}\text { coniferous } \\
\text { forest }\end{array}$ & 15914.27 & 3.87 & 6.16 & \\
\hline \multirow{2}{*}{$\begin{array}{l}\text { Year } \\
2020 \\
\text { (full } \\
\text { year) }\end{array}$} & \multirow[t]{2}{*}{$\begin{array}{l}\text { Trees, } \\
\text { shrubs }\end{array}$} & $\begin{array}{l}\text { broad-leaved } \\
\text { forest }\end{array}$ & 14762.27 & 3.17 & 4.68 & \multirow[t]{2}{*}{19.83} \\
\hline & & $\begin{array}{c}\text { coniferous } \\
\text { forest }\end{array}$ & 15914.27 & 9.52 & 15.15 & \\
\hline \multicolumn{2}{|c|}{ total } & 1 & 1 & 17.85 & 27.89 & 27.89 \\
\hline
\end{tabular}

It can be seen from the above data that the carbon sequestration value of the greening plan implemented by the enterprise from September 2019 to the end of 2020 is 278, 900 yuan.

\subsection{Oxygen release value}

\subsubsection{Calculation method}

According to the Code for Assessment of Forest Ecosystem Service Functions (GB/T 38582-2020), the formula for calculating the oxygen release value of the plant green ecosystem is as follows:

$\mathrm{U}_{\mathrm{O}}=\mathrm{G}_{\mathrm{O}} \times \mathrm{C}_{\mathrm{O}}$

$\mathrm{G}_{\mathrm{O}}=1.19 \mathrm{~A} \times \mathrm{B}_{\text {Year }} \times \mathrm{F}$;

$\mathrm{U}_{\mathrm{O}}$ is to estimate the annual oxygen release value of the stand, unit: yuan $\cdot \mathrm{a}^{-1} ; \mathrm{G}_{0}$ is the annual oxygen release rate of the stand, unit : $t \cdot \mathrm{a}^{-1}$; $\mathrm{C}_{\mathrm{O}}$ is the price of oxygen, unit: yuan -a-1; A stands area, unit $: \mathrm{h} \mathrm{m}^{2}$; $\mathrm{B}_{\text {Year }}$ is the net productivity of measured stand (unit: $\mathrm{t} \cdot \mathrm{hm}^{-2} \cdot \mathrm{a}^{-1}$ ); $\mathrm{F}$ is the correction coefficient of forest ecosystem services.
Referring to the data of carbon sequeathing value, the broad-leaved forest was $13.75 \mathrm{t} \cdot \mathrm{hm}^{-2} \cdot \mathrm{a}^{-1}$, and the coniferous forest was $15.883 \mathrm{t} \cdot \mathrm{hm}^{-2} \cdot \mathrm{a}^{-1}$.

(2) Oxygen price $\left(\mathrm{C}_{\mathrm{O}}\right)$

The average price of oxygen in the website of the Ministry of Health, PRC (http://www. moh. gov. cn) is calculated at RMB $1000 / t$.

(3) Stand area (A)

This time according to the unit area of $1 \mathrm{H}$ square meters for calculation.

(4) Modification coefficient of forest ecosystem services $(\mathrm{F})$

As can be seen from the foregoing, the correction coefficient $\mathrm{F}$ of this project is 1 .

\subsubsection{Calculation Results}

According to the oxygen release value of vegetation per unit area, the annual oxygen release value of the greening measures taken by a company limited liability company from September 2019 to the end of 2020 is shown in Table 4.

\subsubsection{Determination of parameters}

(1) Net productivity of stand (B $\left.B_{\text {Year }}\right)$

Table 4. annual oxygen release value of greening measures taken from September 2019 to the end of 2020

\begin{tabular}{|c|c|c|c|c|c|c|}
\hline Year & Type & $\begin{array}{l}\text { Vegetation } \\
\text { type }\end{array}$ & $\begin{array}{c}\text { Annual oxygen release } \\
\text { value of stand per unit } \\
\text { area } / y u a n \cdot \mathrm{hm}^{-2} \cdot \mathrm{a}^{-1}\end{array}$ & $\begin{array}{c}\text { Forest } \\
\text { area } / h \\
\mathrm{~m}^{2}\end{array}$ & $\begin{array}{l}\text { Annual oxygen } \\
\text { release value of } \\
\text { stand } / \text { ten } \\
\text { thousand yuan } \cdot \mathbf{a}^{-1}\end{array}$ & $\begin{array}{c}\text { Total annual oxygen } \\
\text { release value of } \\
\text { stand/ten thousand } \\
\text { yuan } \cdot \mathbf{a}^{-1} \\
\end{array}$ \\
\hline \multirow{2}{*}{$\begin{array}{c}2019(9 \sim \\
12 \\
\text { months })\end{array}$} & \multirow[t]{2}{*}{$\begin{array}{l}\text { Trees, } \\
\text { shrubs }\end{array}$} & $\begin{array}{l}\text { Road-leaved } \\
\text { forest }\end{array}$ & 16362.5 & 1.29 & 2.11 & \multirow[t]{2}{*}{9.42} \\
\hline & & $\begin{array}{c}\text { Coniferous } \\
\text { forest }\end{array}$ & 18900.77 & 3.87 & 7.31 & \\
\hline \multirow[t]{2}{*}{$\begin{array}{l}\text { Year } 2020 \\
\text { (full year) }\end{array}$} & \multirow[t]{2}{*}{$\begin{array}{l}\text { Trees, } \\
\text { shrubs }\end{array}$} & $\begin{array}{l}\text { Road-leaved } \\
\text { forest }\end{array}$ & 16362.5 & 3.17 & 5.19 & \multirow[t]{2}{*}{23.18} \\
\hline & & $\begin{array}{c}\text { Coniferous } \\
\text { forest }\end{array}$ & 18900.77 & 9.52 & 17.99 & \\
\hline \multicolumn{2}{|c|}{ total } & 1 & 1 & 17.85 & 32.61 & 32.61 \\
\hline
\end{tabular}

It can be seen from the above data that the oxygen

release value of the greening plan implemented by the 
enterprise from September 2019 to the end of 2020 is 326 , 100 yuan.

The service value of carbon sequestration and oxygen release is the sum of the carbon sequestration value and oxygen release value of plant afforestation. The value of carbon sequestration and oxygen release value of the afforestation plan implemented by the enterprise from September 2019 to the end of 2020 is 605,000 yuan. The carbon sequestration value was 278,900 yuan, accounting for $46 \%$; The oxygen release value was 326,100 yuan, accounting for $54 \%$.

\section{Evaluation of environmental value of purifying air}

The main functions of the plant green ecosystem to purify the environment are to absorb toxic substances, block dust, kill bacteria, reduce noise and release negative oxygen ions and terpenoids. Vegetation can absorb carbon dioxide in the air, release oxygen, maintain the balance of carbon and oxygen, absorb toxic gases such as oxygen fluoride, filter dust in the air, reduce photochemical smog and purify radioactive substances through the action of combination. In addition, vegetation can produce negative oxygen ions to make the air fresh and pleasant. The concentration of negative oxygen ions in the air is closely related to human health. When the concentration is $\geq 600$ $/ \mathrm{cm}^{3}$, people can directly feel the freshness of the air. The service value of air environmental purification calculated in this paper mainly includes four indexes, such as the negative ions provided by the plant vegetation, the absorption of sulfur dioxide, the absorption of nitrogen oxides, and the value of dust retention.

\subsection{Provide negative ion value}

\subsubsection{Calculation method}

According to the Code for Assessment of Forest Ecosystem Service Functions (GB/T 38582-2020), the calculation formula of negative ion value is provided as follows:

$\mathrm{U}_{\text {anion }}=5.256 \times 10^{15} \times \mathrm{A} \times \mathrm{H} \times \mathrm{F} \times \mathrm{K}_{\text {anion }}\left(\mathrm{Q}_{\text {anion }}-600\right) \mathrm{L}$;

$\mathrm{U}_{\text {anion }}$ provide negative ion value for the assessment of stand years, unit: yuan $\cdot \mathrm{a}^{-1}$; $\mathrm{K}$ negative ion is negative ion production cost, unit: yuan ${ }^{-1}$; $Q_{\text {anion }}$ is the measured anion concentration in the stand, unit: units $\mathrm{cm}^{-3}$; $\mathrm{L}$ is the lifetime of negative ions, unit :min; $\mathrm{H}$ is the measured stand height, unit :m; A stands area, unit :h $\mathrm{m}^{2} ; \mathrm{F}$ is the correction coefficient of forest ecosystem services.

\subsubsection{Determine parameters}

(1)Negative ion production cost ( $\mathrm{K}$ negative ion)

According to taizhou colli da electronics co., LTD., production scope of $30 \mathrm{~m}^{2}(3 \mathrm{~m})$ high room, power is $6 \mathrm{w}$, negative ion concentration after $1000000 / \mathrm{m}$, the service life of 10 years, the price is RMB 65 each KLD - 2000 anion generator and concluded that the anion production cost of $5.8185 \times 10^{-18}$ yuan /, the anion life expectancy of 10 minutes, electricity per degree of 0.4 yuan. This project is calculated at $5.8185 \times 10^{-18}$ yuan/piece.

(2) Stand concentration of negative ions ( $\left.Q_{\text {anion }}\right)$

The negative ion concentration produced by greening in this project refers to the long-term observation data of 8 ecological stations of Forestry Bureau affiliated to Jilin Forest Industry Group, and further combines with the results of literature research to obtain the negative ion concentration of each vegetation type. This paper calculates the negative ion concentration according to the average value of $1723.4 / \mathrm{cm}^{3}$.

(3) Negative ion lifetime (L)

The amount of negative ions provided by the plant vegetation is mainly based on the concentration of negative ions in the air of the mainland $\left(600 / \mathrm{cm}^{3}\right)$ as a reference. The amount of negative ions provided by the plant vegetation ecosystem is obtained by subtracting the concentration of negative ions in the air of the mainland. According to the relevant experiments, the life of negative ions is 10 minutes, so the life of negative ions in this calculation is $10 \mathrm{~min}$.

(4) Stand height $(\mathrm{H})$

In this study, the ecosystem service value of the greening scheme from September 2019 to the end of 2020 was calculated. The vegetation was all young forests, so the average height of arboreal forest and shrub was taken respectively to estimate the average height of the stand in this project, and the estimated result was $2 \mathrm{~m}$.

(5) Stand area (A)

This time according to the unit area of $1 \mathrm{H}$ square meters for calculation.

(6) Modification coefficient of forest ecosystem services $(\mathrm{F})$

As can be seen from the foregoing, the correction coefficient $\mathrm{F}$ of this project is 1 .

\subsubsection{Calculation results}

According to the value of negative ions provided by forest afforestation per unit area, the annual value of negative ions provided by the afforestation measures taken by a limited liability company from September 2019 to the end of 2020 is shown in Table 5 .

Table 5. Negative ion value of greening measures taken from September 2019 to the end of 2020

\begin{tabular}{|c|c|c|c|c|c|}
\hline Year & Type & $\begin{array}{c}\text { Annual soil } \\
\text { fixation value per } \\
\text { unit area of } \\
\text { stand/yuan } \cdot \mathbf{h m}^{-\mathbf{2}} \cdot \mathbf{a}^{-}\end{array}$ & $\begin{array}{c}\text { Forest area } / \mathbf{h} \\
\mathbf{m}^{\mathbf{2}}\end{array}$ & $\begin{array}{c}\text { Annual soil } \\
\text { fixation value } \\
\text { of }\end{array}$ & $\begin{array}{c}\text { Annual soil } \\
\text { fixation value of } \\
\text { stand/ten } \\
\text { thousand } \mathbf{y u a n} \cdot \mathbf{a}^{-} \\
\mathbf{1}\end{array}$ \\
\hline $\begin{array}{c}2019(9 \sim 12 \\
\text { months })\end{array}$ & $\begin{array}{c}\text { Trees, } \\
\text { shrubs }\end{array}$ & 687.12 & 5.16 & 3545.54 & 0.35 \\
\hline
\end{tabular}




\begin{tabular}{|c|c|c|c|c|c|}
\hline $\begin{array}{c}\text { Year 2020 (full } \\
\text { year) }\end{array}$ & $\begin{array}{c}\text { Trees, } \\
\text { shrubs }\end{array}$ & 687.12 & 12.69 & 8719.55 & 0.87 \\
\hline \multicolumn{2}{|c|}{ Total } & $/$ & 17.85 & 12265.09 & 1.23 \\
\hline
\end{tabular}

It can be seen from the above data that from September 2019 to the end of 2020 , the total value of negative ions provided by the afforestation plan implemented by the enterprise is 12,300 yuan.

\subsection{The absorption of air pollutants and dust retention value of green vegetation}

\subsubsection{Calculation method}

According to the Code for Assessment of Forest Ecosystem Services (GB/T 38582-2020), the calculation formula of pollutant absorption and dust retention value is as follows:

$$
\mathrm{U}_{\mathrm{SO} 2}=\mathrm{G}_{\mathrm{SO} 2} \times \mathrm{K}_{\mathrm{SO} 2}
$$

$\mathrm{U}_{\mathrm{SO} 2}$ is used to evaluate the potential annual dust retention value of the stand, unit: yuan $\cdot \mathrm{a}^{-1}$; $\mathrm{G}$ sulfur dioxide is the annual absorption of sulfur dioxide by the stand $\left(\mathrm{t} \cdot \mathrm{a}^{-1}\right)$. $\mathrm{K}$ sulfur dioxide is the cost of sulfur dioxide treat ment, unit: yuan $\cdot \mathrm{kg}^{-1}$.

\section{$\mathrm{G}_{\mathrm{CO} 2}=\mathrm{Q}_{\mathrm{SO} 2} \times \mathrm{A} \times \mathrm{F} / 1000$}

$\mathrm{G}_{\mathrm{SO} 2}$ is the annual amount of sulfur dioxide absorbed by the stand, unit: $\mathrm{t} \cdot \mathrm{a}^{-1} ; \mathrm{Q}_{\mathrm{SO} 2}$ is the measured amount of $\mathrm{SO}_{2}$ absorbed by the stand per unit area, unit: $\mathrm{kg} \cdot \mathrm{hm}^{-2} \cdot \mathrm{a}^{-1}$; $\mathrm{A}$ is stand area, unit: $\mathrm{hm}^{2} ; \mathrm{F}$ is the correction coefficient of forest ecosystem services.

$$
\mathrm{U}_{\text {oxynitride }}=\mathrm{G}_{\text {oxynitride }} \times \mathrm{K}_{\text {oxynitride; }} \text {; }
$$

$\mathrm{U}_{\text {oxynitride }}$ are used to evaluate the potential annual dust retention value of the stand, unit: yuan $\cdot \mathrm{a}^{-1}$; $\mathrm{G}$ is the annual nitrogen oxides absorbed by the stand $\left(t \cdot \mathrm{a}^{-1}\right)$. $\mathrm{K}$ nitrogen oxides are nitrogen oxides treatment costs, unit: yuan $\cdot \mathrm{kg}^{-}$ 1 .

$\mathrm{G}_{\text {oxynitride }}=\mathrm{Q}_{\text {oxynitride }} \times \mathrm{A} \times \mathrm{F} / 1000$;

$\mathrm{G}_{\text {oxynitride }}$ is the annual nitrogen oxides absorbed by the stand $\left(\mathrm{t} \cdot \mathrm{a}^{-1}\right)$. Q $\mathrm{Q}_{\text {oxynitride }}$ is the measured amount of nitrogen oxides absorbed by the stand per unit area $\left(\mathrm{kg} \cdot \mathrm{hm}^{-2} \cdot \mathrm{a}^{-1}\right)$; A is stand area, unit: $\mathrm{hm}^{2} ; \mathrm{F}$ is the correction coefficient of forest ecosystem services.

$$
\begin{aligned}
& \mathrm{U}_{\text {lay the dust }}=\left(\mathrm{G}_{\mathrm{TSP}}-\mathrm{G}_{\mathrm{PM} 10}-\mathrm{G}_{\mathrm{PM} 2.5}\right) \mathrm{K}_{\mathrm{TSP}}+\mathrm{U}_{\mathrm{PM} 10}+\mathrm{U}_{\mathrm{PM} 2.5} ; \\
& \mathrm{U}_{\mathrm{PM} 10}=\mathrm{C}_{\mathrm{PM} 10} \times \mathrm{G}_{\mathrm{PM} 10} ; \\
& \mathrm{U}_{\mathrm{PMA} 2.5}=\mathrm{C}_{\mathrm{PM} 2.5} \times \mathrm{G}_{\mathrm{PM} 2.5} ; \\
& \mathrm{G}_{\mathrm{TSP}}=\mathrm{Q}_{\mathrm{TSP}} \times \mathrm{A} \times \mathrm{F} / 1000 ; \\
& \mathrm{G}_{\mathrm{PM} 10}=\mathrm{Q}_{\mathrm{PM} 10} \times \mathrm{A} \times \mathrm{F} / 1000 ; \\
& \mathrm{G}_{\mathrm{PM} 2.5}=\mathrm{Q}_{\mathrm{PM} 2.5} \times \mathrm{A} \times \mathrm{F} / 1000 ;
\end{aligned}
$$

$\mathrm{U}_{\text {lay the dust }}$ is an assessment of potential annual dust retention value of a stand, unit: yuan $\cdot \mathrm{a}^{-1} ; \mathrm{G}_{\text {TSP }}$ is an assessment of potential annual arrears of TSP in a stand, unit: $t \cdot a^{-1} ; G_{P M 10}$ is an assessment of potential annual delinquent PM10 in a stand, unit: $\mathrm{kg} \cdot \mathrm{a}^{-1} ; \mathrm{G}_{\mathrm{PM} 2.5}$ is an assessment of the potential annual overdue PM2. 5 of the stand, unit: $\mathrm{kg} \cdot \mathrm{a}^{-1} ; \mathrm{K}_{\mathrm{TSP}}$ is the cost of dust removal, unit: Yuan $\cdot \mathrm{kg}^{-1}$; UPM10 is to evaluate the value of potential annual delinquent PM10 in a stand, unit: Yuan $\cdot \mathrm{a}^{-1}$; UPM2. 5 is to evaluate the value of potential annual delayed PM2. 5 in a stand, unit: yuan $\cdot \mathrm{a}^{-1}$.

\subsubsection{Parameters Determination}

Since PM10 is emitted by organized emission sources and TSP is emitted by unorganized emission sources in the plant area of this project, there is no PM2. 5 emission. Among them, PM10 is discharged to the high altitude through the exhaust pipe, and the vegetation in the factory area has a small amount of lag, so the dust retention value in this evaluation is only calculated as the value generated by the delayed TSP.

(1) Cost of pollutant treatment $(\mathrm{K})$

The treatment costs of sulfur dioxide and nitrogen oxides in the atmosphere and dust removal are shown in Table 6.

Table 6. Treatment cost and dust removal cost of sulfur dioxide, particulate matter and nitrogen oxide in the atmosphere

\begin{tabular}{|c|c|c|c|}
\hline $\begin{array}{c}\text { Air pollutant } \\
\text { control }\end{array}$ & $\begin{array}{c}\text { Sulfur } \\
\text { dioxide }\end{array}$ & $\begin{array}{c}\text { Nitrogen } \\
\text { oxide }\end{array}$ & Dust fall \\
\hline Cost $(y u a n / \mathrm{kg})$ & 1.2 & 0.63 & 0.15 \\
\hline
\end{tabular}
(Q)

(2) Annual pollutant absorption per unit area of stand

According to China Biodiversity Research Report, the pollutant absorption capacity of different vegetation is shown in Table 7.

Table 7. Pollutant absorption capacity of different vegetation

\begin{tabular}{|c|c|c|c|}
\hline $\begin{array}{c}\text { Vegetational } \\
\text { form }\end{array}$ & $\begin{array}{c}\text { Sulfur } \\
\text { dioxide } \\
\mathbf{k g} /\left(\mathbf{h ~ m}^{2} \cdot \mathbf{a}\right)\end{array}$ & $\begin{array}{c}\text { Nitrogen } \\
\text { oxide } \\
\mathbf{k g} /\left(\mathbf{h ~ m}^{2} \cdot \mathbf{a}\right)\end{array}$ & $\begin{array}{c}\text { Lay the } \\
\mathbf{d u s t k g} /(\mathbf{h} \\
\left.\mathrm{m}^{2} \cdot \mathbf{a}\right)\end{array}$ \\
\hline $\begin{array}{c}\text { Broad-leaved } \\
\text { forest }\end{array}$ & 88.65 & 6.0 & 10.11 \\
\hline $\begin{array}{c}\text { Coniferous } \\
\text { forest }\end{array}$ & 215.60 & 6.0 & 33.2 \\
\hline
\end{tabular}

(3) Stand area (A)

This time according to the unit area of $1 \mathrm{H}$ square meters for calculation.

(4) Modification coefficient of forest ecosystem services $(\mathrm{F})$

As can be seen from the foregoing, the correction coefficient $\mathrm{F}$ of this project is 1 .

\subsubsection{Calculation Results}

In summary, the values of SO2 and NOx absorption and dust retention of each vegetation type in this project can be calculated as shown in Table 8 . 
Table 8. Value of absorbing sulfur dioxide, nitrogen oxides and dust retention

\begin{tabular}{|c|c|c|c|c|c|c|c|c|}
\hline \multirow{2}{*}{ Year } & \multirow{2}{*}{ Type } & \multirow{2}{*}{$\begin{array}{l}\text { vegetational } \\
\text { form }\end{array}$} & \multicolumn{3}{|c|}{$\begin{array}{l}\text { Annual absorption value of } \\
\text { pollutants per unit area of } \\
\text { stand } / \text { yuan } \cdot h^{-2} \cdot \mathbf{a}^{-1}\end{array}$} & \multirow{2}{*}{$\begin{array}{c}\text { Forest } \\
\text { area } / \mathrm{h} \mathrm{m} \mathrm{m}^{2}\end{array}$} & \multirow{2}{*}{$\begin{array}{c}\text { The annual } \\
\text { pollutant } \\
\text { absorption } \\
\text { value of the } \\
\text { stand/ten } \\
\text { thousand } \\
\text { yuan } \cdot \mathbf{a}^{-1}\end{array}$} & \multirow{2}{*}{$\begin{array}{c}\text { Total value of } \\
\text { pollutants } \\
\text { absorbed by the } \\
\text { stand per } \\
\text { year/ten } \\
\text { thousand } \\
\text { Yuan } \cdot \mathbf{a}^{-1}\end{array}$} \\
\hline & & & $\begin{array}{l}\text { sulfur } \\
\text { dioxide }\end{array}$ & $\begin{array}{l}\text { nitric } \\
\text { oxide }\end{array}$ & $\begin{array}{l}\text { lay the } \\
\text { dust }\end{array}$ & & & \\
\hline \multirow{2}{*}{$\begin{array}{l}2019(9 \sim \\
12 \\
\text { months })\end{array}$} & \multirow{2}{*}{$\begin{array}{l}\text { Trees, } \\
\text { shrubs }\end{array}$} & $\begin{array}{c}\text { broad- } \\
\text { leaved forest }\end{array}$ & 106.38 & 3.78 & 1. 52 & 1. 29 & 0.01 & \multirow{2}{*}{0.11} \\
\hline & & $\begin{array}{c}\text { coniferous } \\
\text { forest }\end{array}$ & 258.72 & 3.78 & 4. 98 & 3.87 & 0.10 & \\
\hline \multirow{2}{*}{$\begin{array}{l}\text { Year } 2020 \\
\text { (full year) }\end{array}$} & \multirow{2}{*}{$\begin{array}{l}\text { Trees, } \\
\text { shrubs }\end{array}$} & $\begin{array}{c}\text { broad- } \\
\text { leaved forest }\end{array}$ & 106. 38 & 3.78 & 1. 52 & 3. 17 & 0.04 & \multirow{2}{*}{0.29} \\
\hline & & $\begin{array}{c}\text { coniferous } \\
\text { forest }\end{array}$ & 258.72 & 3.78 & 4. 98 & 9.52 & 0.25 & \\
\hline \multicolumn{2}{|c|}{ Total } & I & I & I & I & 17.85 & 0.40 & 0.40 \\
\hline
\end{tabular}

It can be seen from the above table that from September 2019 to the end of 2020, the annual value of pollutant absorption and dust retention in the greening plan implemented by the enterprise is 4, 000 yuan. Among the total value of $\mathrm{SO}_{2}$ and $\mathrm{NO}_{\mathrm{x}}$ absorption and dust retention in the vegetation type, the coniferous type has a higher value, while the broad-leaved type has a lower value.

The total value of the greening measures taken by a company limited liability company from September 2019 to the end of 2020 to purify the atmosphere environment is 1.63 yuan. Among them, the negative ion value is 12 , 300 yuan, accounting for $75 \%$; The value of pollutant absorption and dust retention is 4,000 yuan, accounting for $25 \%$.

\section{Conclusion}

The total carbon sequestration and oxygen release value of the greening measures taken by a company limited liability company from September 2019 to the end of 2020 is 60.5 yuan. The carbon sequestration value was 278,900 yuan, accounting for $46 \%$; The oxygen release value was 326,100 yuan, accounting for $54 \%$.

The total value of the greening measures taken by a company limited liability company from September 2019 to the end of 2020 to purify the atmosphere environment is 1.63 yuan. Among them, the negative ion value is 12 , 300 yuan, accounting for $75 \%$; The value of pollutant absorption and dust retention is 4, 000 yuan, accounting for $25 \%$.

The ecological damage caused by excessive emission of the enterprise is RMB 6, 978, 303 yuan. The total value of ecosystem services of the greening scheme adopted by a company limited liability company from September 2019 to the end of 2020 is RMB 621, 300 yuan, which can be partially offset. Therefore, the final ecological damage of the enterprise should be RMB 6, 357, 003 yuan.

\section{Reference}

1. Wei Huilan, Qi Yingjun. Journal of Beijing Forestry
University, 2016, 38(2). (in Chinese with English abstract)

2. Han Song, He Tairong, Ban Rongbang. Analysis of ecosystem service value of Shengjinhu Wetland [J]. China Soil and Water Conservation SWCC, 2015, (6)

3. Sun Qiwu. Discussion on Plant Greening Design and Maintenance Management [J]. Modern Horticulture, 2017(4)

4. FAN Y. Evaluation and analysis of forest ecosystem service function value in Ma 'anshan City [J]. Jiangsu Forestry Science and Technology, 2019, 46(6)

5. Sun Qingxiang, Zhou Huarong. Forest ecosystem services and their value assessment in the Altai Mountains [J]. Arid Land Geography, 2020

6. ZHANG Fang, CHEN Yongfang, AN Yulin, et al. Evaluation of ecosystem service function of Daqingshan forest ecosystem in Inner Mongolia [J]. Forestry Survey and Design of Inner Mongolia, 2020, 43(6)

7. Huang Menglan, Chen Maolin. Study on Supply and Demand Evaluation of Urban Green Space [J]. Shihezi Science and Technology, 2020 